\title{
Pentingnya Mempelajari Administrasi dan Supervisi Pendidikan
}

\author{
Agung Syukriardi \\ Universitas Negeri Padang \\ Indonesia \\ Agungsyukriardi98@gmail.com
}

\author{
Hade Afriansyah \\ Universitas Negeri Padang \\ Indonesia \\ $\underline{\text { hadeafriansyah@ fip.unp.ac.id }}$
}

\begin{abstract}
Abstrak-This study aims to find out what is the importance of studying administration and supervision of education for prospective teachers. This study uses a qualitative approach with qualitative descriptive methods. The subjects of this study consisted of principals, boards of teachers and staff. Data collection consists of observation, interviews and documentation. Data analysis techniques include editing, categories, displaying data and interpretation. Conclusions in this study namely the importance of studying education administration is that we can know that the administration is an educational institution which is a major source of management in regulating the teaching and learning process in an orderly manner so that the most important goal is created at the educational institution.A profession is a position or job that demands expertise from its members. That is, it cannot be done by anyone who is not trained and is not specifically prepared to do the work. Education personnel are members of the community who are devoted and appointed to support the implementation of education. Included in the education staff are: heads of education units, educators and other education personnel.
\end{abstract}

Kata kunci -(Administrasi Pendidikan, Pendidik, Tenaga Kependidikan)

\section{PENDAHULUAN}

Administrasi sebagai suatu kegiatan bersama terdapat dimana-mana selama ada manusai yang hidup dan bekerja sama dalam kelompok. Jika melihat sebuah pabrik bekerja menghasilkan semacam benda sebagai produknya, maka disitu kita melihat adanya administasi. Jika kita melihat suatu lembaga yang melatih dan memberikan suatu pelajaran yang akhirnya mereka mendapatkan sertifikat dari proses pendidikan itu, maka disitu ada proses adminstrasi pendidikan. Jika kita melihat suatu lembaga yang mempunyai suatu organisasi yang tersusun baik aau terencana, maka disitu kita melihat adanya manajemen.

Peningkatan mutu pendidikan ditentukan oleh kesiapan sumber daya manusia yang terlibat dalam proses pendidikan. Tenaga pendidik merupakan sala satu factor penentu tinggi rendahnya mutu hasil pendidikan.

Tenaga pendidik merupakan tenaga professional yang bertugas merencanakan dan melaksanakan proses pebelajaran, menilai hasil pembelajaran, melakukan pembinaan dan penelitian, serta melakukan penelitian dan pengabdian kepada masyarakat. Hal tersebut tidak dapat disangkal karena lembaga pendidikan formal adalah dunia kehidupan tenaga pendidik. Sebagian besar waktu tenaga pendidik ada di sekolah, sisanya ada di rumah dan di masyarakat.

Tenaga pendidik sebagai pekerja harus berkemampuan yang meliputi penguasaan materi pelajaran, penguasaan professional tenaga pendidik dan pendidikan, penguasaan cara-cara menyesuaikan diri dan berkepribadian untuk melaksanakan tugasnya, disamping itu tenaga pendidik haru smerupakan pribadi yang berkembang dan bersifa dinamis. Hal ini sesuai yang terkandung dalam Undang-Undang No. 20 tahun 2003 tentang Sistem Pendidikan Nasional bahwa pendidik dan tenaga kependidikan berkewajiban 1) menciptakan suasana pendidikan yag bermakna, meneynangkan, kreatif, dinamis, dan logis, 2) mempunyai komitmen secara professional unutk meningkatkan mutu pendidikan dan 3) member keteladanan dan menjaga nama baik lembaga, profesi,dan kedudukan sesuai dengan kepercayaan yang diberikan kepadanya.

Harapan dalam Undang-Undang tersebut menunjukkan adanya perubahan paradigm pola mengajar tenaga pendidik yang pada mulanya sebagai sumber informasi bagi para siswa dan selalu mendominasi kegiatan dalam kelas berubah menuju paradigm yang memposisikan tenaga pendidik sebagai fasilitator dalam proses pembelajaran dan selalu terjadi interaksi antara tenaga pendidik dengan siswa maupun antara siswa dengan siswa di dalam kelas. Kenyataan ini mengharuskan tenaga pendidik untuk selalu meningkatkan kemampuannya terutama memberikan keteladanan, mambangun kemauan, dan mengembangkan kreativitas peserta didik dalam proses pembelajran.

\section{METODE PENELITIAN}

Metode penelitian ilmiah hendaknya disusun dengan metode dan langkah-langkah yang sistematis sehing amemudahkan melakukan penelitian. Pada artikel ini penelitian ini menggunakan metode pendekatan kualitatif dengan 
metode deskriptif kualitatif. Sebyek penelitian terdiri dari kepala sekolah, dewan guru dan staf. Sumber data dalam penelitian ini dapat dibedakan menjadi dua, yaitu manusia (human) dan buka manusia. Sumber data manusia berfungsi sebagai subjek atau informasidan (key information) data yang diperoleh melalui informasi berupa soft data (data lunak) seperti hasil wawancara dan observasi denga kepala sekolah dan guru. Sedangkan sumber data bukan manusia berupa dokumen yang relevan dengan prermasalahan penelitian seperti peristiwa atau aktifitas yang ada kaitannya dengan permasalahan penelitian. Data yang diperoleh melalui dokumen bersifat hard data yang berkenaan dengan sekolah.

\section{KAJIAN TEORI DAN PEMBAHASAN}

A. Pentingnya Mempelajari Administrasi dan Supervisi Pendidikan

Administrasi pendidikan adalah keseluruhan proses kerjasama yang baik antara dua orang atau lebih onsdengan memanfaatkan semua sumber personil dan materi yang tersedia dan sesuai untuk mencapai tujuan pendidikan yang telah ditetapkan secara efektif dan efisien.

Dari pengertian diatas dapat kita tarik kesimpulan, bahwa pentinnya kita sebagai mahasiswa dan calon guru dalam mempelajari administrasi pendidikan tersebut adalah :

1. Kita dapat mengetahui bahwa administrasi itu adalah suatu lembaga pendidikan yang merupakan suatu sumber utama manajemen dalam mengatur proses belajar mengajar dengan tertib ehingga tercapainya suatu tujuan terpenting pada lembaga pendidikan tersebut.

2. Kita dapat mengetahui bagaimana prosesproses belajarnya suatu administrasi pendidikan yang sebenarnya harus dilakukan sebagai seorang pendidik. Karna dalam administrasi pendidikan itu tidak hanya membahas tentang catat-mencatat, keuangan, melaiankan bagaimana kita dapat melaksanakan proses organisasi itu sesuai dengan apa yang telah kita rencanakan secara efektif dan efisien.

Dengan demikian diharapkan kita dapat termotifasi untuk memberi sesuatu yang berbeda yang mengarah pada proses perbaikan dalam dunia pendidikan, setelah kit amempeajari administrasi pendidikan kaarena seorang guru selainmenjadi pelaksana administras juga bertanggung jawab agar pendidikan dapat berlangsung dengan baik. (Afriansyah, 2019)

\section{B. Konsep Profesi Pendidik dan Tenaga Kependidikan \\ 1) Konsep Profesi}

Profesi adalah suatu jabatan atau pekerjaan yang menuntut keahlian dari para anggotanya. Artinya, tidak bisa dilakuakan oleh sembarang orang yang tidak terlatih dan tidak disiapkan secara khusus untuk melakukan pekerjaan itu.

Menurut pasal 39 A ayat 2 UUSPN No 20 Tahun 2003 menyatakan bahwa pendidikan merupakan tenaga professional yang bertugas merencanakan dan pelaksanaan proses pembelajaran, menialai hasil pembelajaran, melakaukan pembimbingan dan pelatihan serta melakukan penelitian dan pengabdian kepada masyarakat teruatama bagi pendidik pada perguruan tinggi.

Adapun beberapa criteria untuk menentukan ciri-ciri suatu profesi yaitu :

a. Ada standard untuk kerja yang baku dan jelas.

b. Ada lembaga pendidikan khusus yan menghasilkan pelakunya dengan program dan jenjang pendidikan yang baku serta memiliki standar akademik yang memadai dan bertanggung jawab tentang pengembangan ilmu pengetahuan yang meladasi profesi itu.

c. Ada organisasi profesi yang mewadahi para pelakunya untuk mempertahankan dan memperjuangkan eksistensi dan kesejahteraannya.

d. Ada etika dank ode etik yang mengatur perilaku etik para pelakunya dalam memperlakukan kliennya.

e. Ada system imbalan terhadap jasa layanannya yang adil dan baku.

f. Ada pengakuan msyarakat (professional, penguasa dan awam) terhadap pekerjaan itu sebagai suatu profesi.(Natawidjaja, 1989)

\section{2) Pendidik dan Profesi Pendidik}

Guru adalah jabatan semiprofessional karena : "... the training (of teacher) is shorter, their status less legitimated (low or moderate), their right to privileged communication less established; there is less of a specialized knowledge, and they have less autonomy from supervision or societal control than 'the professions'..."

Guru harus dilihat sebagai profesi yang baru muncul, dan karena itu mempunyai status yang lebih tinggi dari jabatan semiprofesional, bahkan mendekati jabatan professional penuh. Pada saat sekarang, seperti telah dijelaskan juga didepan, sebagian orang cenderung menyatakan guru sebagai suatu profesi, dan sebagian lain tidak mengakuinya. Oleh sebab itu, dapat dapat dikatakan jabatan guru sebagian, tetapi bukan seluruhnya adalah jabatan professional, namun sedang bergerak kearah itu. Kita di Indonesia dapat merasakan jalan kearah itu mulai ditapaki, misalnya dengan adanya peraturan dari Menteri Pendidikan 
dan Kebudayaan bahwa yang boleh menjdai guru hanya yang mempunyai akta mengajar yang dikeluarkan oleh Lembaga Pendidikan Tenaga Kependidikan (LPTK). Selain itu juga guru diberi penghargaan oleh pemerintah melalui Keputusan Menpan No. 26 tahun 1989, dengan member tunjangan fungsional sebagai pengajar dan dengan kemungkinan kenaikan pangkat yang terbaru.(Amita, 1969)

Ciri-ciri profesionalisasi jabatan guru adalah :

a. Para guru akan bekerja hanya sematamata membri pelayanan kemanusiaan dari pada usaha untuk kepentingan pribadi.

b. Para guru secara hukum dituntut untuk memenuhi berbagai persyaratan untuk mendapatkan lisensi mengajar serta persyaratan yang ketat untuk menjadi anggota organisasi guru.

c. Para guru dituntut memiliki pemahaman serta keterampilan yang tinggi dalam hal bahan pengajar, metode, anak didik, dan landasan kependidikan.

d. Para guru dalam organisasi professional, memiliki publikasi professional yang dapat melayani para guru, sehingga tidak ketinggalan, bahkan selalu mengikuti perkembangan yang terjadi.

e. Para guru, diusahakn untuk selalu mengikuti kurss-kursus, seminar, kovensi serta terlibat secara luas dalam berbagai kegiatan in service.

f. Para guru diakui sepenuhnya sebagai suatu karier hidup (a life career).

g. Para guru memiliki nilai dan etika yang berfungsi secara nasionalmaupun secara local.(Richey, 1974)

Kode etik guru adalah landasan moral dan pedoman tingkah laku guru warga PGRI dalam melaksanakan penggilan pengabdiannya bekerja sebagai guru.

Tujuan kode etik professional adalah untuk kepentingan dan organisasi profesi itu sendiri yaitu untuk :

a. Menunjang tinggi martabat profesi

b. Menjaga dan memlihara kesejahteraan anggotanya

c. Meningkatkan pengabdian para anggota profesi

d. Meningkatkan mutu profesi

e. Meningkatakan mutu organisasi profesi. (PGRI, 1973)

Kode etik ditetapkan oleh anggota profesi. Kode etik guru dietapkan oleh anggota prfesi guru yang bergabung dalam wadah PGRI. Kode etik ini dijadikan pedoman bertindak bagi seluruh anggota organisasi atau profesi tersebut. Sanksi terhadap pelanggaran kode etik berlaku bagi anggota dengan menggunakan sanksi organisasi profesi.

Kode etik guru Indonesia ditetapkan dalam kongres PGRI pada tahun 1973 pada kongres ke XIII di Jakarta. Kemudian disempurnakan pada Kongres ke XVI tahun 1989 di Jakarta.(Natawidjaja, 1989)

Secara konseptual dan umum, ruang lingkup kerja guru ialah mencakup aspekaspek :

a. Kemampaun professional mencakup :

1. Penguasaan materi pelajaran yang terdiri atas penguasaan bahan yagn harus diajarkan dan konsep-konsep dasar keilmuan dari bahan yang diajarkan.

2. Penguasaan dan penghayatan atas landasan dan wawasan kependidikan dan keguruan.

3. Penguasaan dan proses-proses kependidikan, keguruan dan pembelajaran.

b. Kemampuan sosial yang mencakup kemampuan untuk menyesuaikan diri kepada tuntutan kerja dan lingkungan sekitar pada waktu membawakan tugasnya sebagai guru.

c. Kamampun pribadi mencakup :

1. Penampilan penghayatan dan penampilan nilai-nilai yang seyogyanya dianut oleh seorang guru.

2. Penampilan sikap positif terhadap keseluruhan tugasnya sebagai guru, dan terhadap keseluruhan situasi pedidikan beserta unsure-unsurnya

\section{3) Tenaga Kependidikan}

Tenaga kependidikan adalah anggota masyarakat yang mengabdikan diri dan diangkat untuk menunjang penyelenggaraan pendidikan. Yang termasuk dalam tenaga kependidikan adalah : kepala satuan pendidikan, pendidik dan tenaga kependidikan lainnya.(Gunawan, 2002)

\section{KESIMPULAN}

Pentingnya mempelajari administrasi pendidikan adalah kita dapat mengetahui bahwa administrsi itu adalah suatu lembaga pendidikan yang merupakan suatu sumber utama manajemen dalam mengatur proses belajar mengajar dengan tertib sehingga terciptanya suatu tujuan terpenting pada lembaga pendidikan tersebut.

Profesi adalah suatu jabatan atau pekerjaan yang menuntut keahlian dari para anggotanya. Artinya, tidak bisa dilakuakan oleh sembarang orang yang tidak terlatih dan tidak disiapkan secara khusus untuk melakukan pekerjaan itu. Tenaga kependidikan adalah anggota masyarakat yang mengabdikan diri dan diangkat untuk menunjang 
penyelenggaraan pendidikan. Yang termasuk dalam tenaga kependidikan adalah : kepala satuan pendidikan, pendidik dan tenaga kependidikan lainnya.

\section{Daftar Pustaka}

Afriansyah, H. (2019). Administrasi dan Supervisi Pendidikan. Padang: osf.io. Retrieved from http://doi.org/10.17605/OSF.IO/TZ4VF

Amita, E. (1969). The Semiprofesions and Their Organizations, Theacher Nurses and Social Workers. New York: Free Press.
Gunawan, A. H. (2002). Administarsi Sekolah. Jakarta: PT Rineka Cipta.

Natawidjaja, R. (1989). Meningkatkan Kualitas Profesi Guru SD Melalui Pemantapan Lembaga Pendidikannya. Bandung.

PGRI. (1973). Buku Kenang-Kenangan Kongres PGRI ke XIII 21 s.d 25 Nopember 1973 dan HUT PGRI ke XXII.

Richey, R. W. (1974). Preparing for a Career in Education. New York: Mc Graw Hill. 